\title{
FACTORS ASSOCIATED WITH ELDERLY'S SATISFACTION IN INTEGRATED HEALTH SERVICE POST IN VILLAGE TOBIMEITA DISTRICT OF NAMBO CITY OF KENDARI
}

\author{
Sartini Risky MS1, Dewi Sari Pratiwi², Muhammad Ikhsan Akbar ${ }^{3}$ \\ ${ }^{1,2,3}$ College of Health Sciences Mandala Waluya Kendari, Southeast Sulawesi, Indonesia \\ Corresponding Author : Sartini Risky MS \\ Email : risky.sarjan87@gmail.com
}

\begin{abstract}
Background: Based on the results of interviews with researchers, six out of ten elderly said they were not satisfied with the service because the starting time for integrated post services was sometimes late, the lack of information obtained was related to elderly integrated service post activities. First person said he was satisfied with the service but still complained about the irregular timing of the integrated service post activities. Research is aimed to determine Factors-Factors Associated With Satisfaction Elderly In Integrated Service Post In Village Tobimeita District of Nambo city of Kendari.

Methods: This type of research uses research quantitative design with cross-sectional study population of fifty six people. Sampling using purposive sampling with a sample size of fifty six respondents. The data is processed by using a test Fisher's exact test and continued with the test Coefficient Phi.
\end{abstract}

Result: Based on the results of statistical tests there is a strong relationship between service quality and the level of satisfaction of the elderly with $p$ value $0.000<\alpha 0.05$, there is a moderate relationship between service and the satisfaction level of the elderly with $\mathrm{p}$ value $0.000<\alpha 0.05$, and there is a strong relationship between the attitude of officers with elderly satisfaction level $\mathrm{p}$ value $0.000<\alpha 0.05$.

Conclusion: Researchers suggest that active remind and motivate the elderly to follow integrated service post elderly, other than that in running its role officers also should have to be friendly to the elderly so that the elderly feel happy to follow integrated service post elderly.

Key words: Integrated Service, Post, Elderly, Satisfaction 


\section{INTRODUCTION}

One form of health care for the elderly in the community is the Integrated Healthcare Center for the elderly. Integrated Healthcare Center is a public health service facility established in small villages that are not reached by hospitals or clinics(1). Someone is said to be elderly when they are 60 years old or more, because certain factors cannot fulfill their basic needs both physically, spiritually and socially (2). In Indonesia, the population aged 60 years and over or the elderly (elderly) is estimated to increase from 18 million in 2012 to 80 million in 2030, or an increase of $63 \%$ to $64 \%$. The number of elderly people in Southeast Sulawesi spread across several sub-districts in 2017 amounted to 554,278 people, for 2018 the number was 560,596 people, while for 2019 the number was 569,103 people, this happened along with the increase in life expectancy (3)

Satisfaction is a description of someone's expectations for services or services that match expectations or not. Elderly Integrated Healthcare Center are visitors who immediately feel how Integrated Healthcare Center provide services to the elderly, in which there is the role of cadres who try to improve all services and activities in implementing Integrated Healthcare Center for the elderly so that the elderly feel the expectations that are desired (4). Elderly satisfaction with elderly Integrated Healthcare Center health services will arise if the services provided by Integrated Healthcare Center health workers are in accordance with the 5 table system. The service is influenced by several factors such as quality or service quality, the attitude of Integrated Healthcare Center officers, and health services.(5)

An accurate level of patient satisfaction is needed in an effort to improve the quality of health services (6). Patients will feel satisfied if the Integrated Healthcare Center officers 'attitude in providing health services is the same or exceeds their expectations and vice versa, the patient's dissatisfaction or feelings of disappointment will arise if the Integrated Healthcare Center officers' attitude in providing health services is not in accordance with the patient's expectations. If the attitude of Integrated Healthcare Center officers at a health service facility matches their expectations, patients will always come to the health service facility for treatment. Patients will always seek health services in facilities where the performance and attitude of the health service Integrated Healthcare Center officers can meet expectations or not disappoint the patient. (7)

Abeli Public Health Center is one of the health service providers located in Nambo sub-district, Tobimeita Village and has an elderly Integrated Healthcare Center. Based on the latest data, there were 235 Integrated Healthcare Center for elderly in 2017, 193 people in 2018 and 35 people in 2019. Meanwhile, in 2020, there were 56 elderly people who actively participated in the elderly Integrated Healthcare Center. Elderly Integrated Healthcare Center held by Puskesmas Abeli as a routine program on the 4th of each month (8)

Based on the results of interviews with researchers, 6 out of 10 elderly people said they were not satisfied with the service because the starting time for Integrated Healthcare Center services was sometimes late, the lack of information obtained related to elderly Integrated Healthcare Center activities. 1 person said he was satisfied with the service but still complained about the irregular timing of the Integrated Healthcare Center activities. Based on the above background, the researchers are interested in conducting research on " Factors Related to Elderly Satisfaction in Elderly Integrated Healthcare Center in Tobimeita Village, Nambo District, Kendari City "

\section{METHOD}

This type of research uses a quantitative study with a nonexperimental design with a Cross Sectional Study approach. The research was carried out in June 2020 at the Elderly Integrated 
Healthcare Center, Tobimeita Village, Nambo District, Kendari City. The total population is 56 people and a sample of 56 people using non-probability sampling techniques with purposive sampling technique. The instrument used was a questionnaire. Collecting data using secondary data, namely by taking data from institutions and primary data, namely data obtained directly from respondents. Data analysis used univariate analysis and bivariate analysis.
RESULT

a. Respondent characteristics

Table 1. Characteristics of Respondents at the Elderly Integrated Healthcare Center in Tobimeita Village, Nambo District, Kendari City

\begin{tabular}{lll}
\hline Age & $\mathbf{N}$ & $\mathbf{\%}$ \\
\hline $45-49$ & 17 & $30,4 \%$ \\
$60-75$ & 39 & $69,6 \%$ \\
Total & $\mathbf{5 6}$ & $\mathbf{1 0 0 \%}$ \\
\hline Gender & $\mathbf{N}$ & $\mathbf{\%}$ \\
\hline Male & 15 & 26,8 \\
Female & 41 & 73,2 \\
Total & $\mathbf{5 6}$ & $\mathbf{1 0 0 \%}$ \\
\hline \multicolumn{1}{c}{ Table } & 1.Shows that of the 56
\end{tabular}

respondents, most were 60-75 years old, namely 39 respondents $(69.6 \%)$ and the rest were 45-59 years old, namely 17 respondents (30.4\%) with 15 respondents $(26,8 \%)$ were male, while 41 respondents $(73.2 \%)$ were female.

\section{b. The Relationship between Service Quality and Elderly Satisfaction at Integrated Healthcare Center Elderly}

Tabel 2. Relationship between Service Quality and Elderly Satisfaction in Elderly Integrated Healthcare Center

\begin{tabular}{|c|c|c|c|c|c|c|c|c|}
\hline \multirow{3}{*}{$\begin{array}{l}\text { Service } \\
\text { Quality }\end{array}$} & \multicolumn{4}{|c|}{ Satisfaction Level } & \multirow{2}{*}{\multicolumn{2}{|c|}{ Total }} & \multirow{2}{*}{$\begin{array}{c}\text { Uji } \\
\text { Fisher's } \\
\text { Exact }\end{array}$} & \multirow[t]{2}{*}{$\begin{array}{c}\text { Nilai } \\
\text { phi }\end{array}$} \\
\hline & \multicolumn{2}{|c|}{ Not satisfied } & \multicolumn{2}{|c|}{ Satisfied } & & & & \\
\hline & $\mathbf{n}$ & $\%$ & $\mathbf{n}$ & $\%$ & $\mathbf{n}$ & $\%$ & \multirow{4}{*}{$\mathbf{0 , 0 0 0}$} & \multirow{4}{*}{$\mathbf{0 , 7 0 7}$} \\
\hline Well & 3 & 5,4 & 29 & 51,8 & 32 & 57,1 & & \\
\hline Less & 19 & 33,9 & 5 & 8,9 & 24 & 42,9 & & \\
\hline Total & 22 & 39,3 & 34 & 60,7 & 56 & 100 & & \\
\hline
\end{tabular}

Table 2 explains the relationship satisfaction level of the elderly at the elderly between service quality and elderly Integrated Healthcare Center by $29(51.8 \%)$ satisfaction at the Elderly Integrated respondents. Meanwhile, of the $24(42.9 \%)$ Healthcare Center in Tobimeita Village, respondents whose service quality was not Nambo District, Kendari City. It shows that of the 56 respondents there are $32(57.1 \%)$ respondents whose service quality is good, it is found that respondents who get the quality of their services are not satisfied with the satisfaction level of the elderly at the elderly Integrated Healthcare Center by $3(5.4 \%)$ of respondents, and those whose service quality is good at find respondents who get the quality of service are satisfied with the good, it was found that respondents who received the quality of their services were not satisfied with the satisfaction level of the elderly at the elderly Integrated Healthcare Center as many as 19 (33.9\%) respondents, and the quality of service was not good. The quality of the service is satisfied with the satisfaction level of the elderly in the elderly Integrated Healthcare Center for 5 (8.9\%) respondents. Based on the results of 
statistical tests using the Fisher's Exact Test, it was found that $p=0.000$ and which means it is smaller than the value of $\alpha=0.05$. So $\mathrm{Ho}$ is rejected and $\mathrm{Ha}$ is accepted means that the research hypothesis is accepted (There is a strong relationship between the quality of service and the level of satisfaction of the elderly at the Elderly Integrated Healthcare Center in the Tobimeita Village, Kendari City). The results of the relationship closeness test using the Cramers test obtained the value of the phi coefficient of 0.707 and entered the coefficient interval 0.60-799 with the strong category. This shows that there is a strong relationship between the quality of service and the level of satisfaction of the elderly at the Elderly Integrated Healthcare Center in Tobimeita Village, Nambo District, Kendari City.

\section{c. Service Relationship with Elderly Satisfaction at Elderly Integrated Healthcare Center}

Table 3. Service Relationship with Elderly Satisfaction at Elderly Integrated Healthcare Center in Tobimeita Village, Nambo District, Kendari City..

\begin{tabular}{|c|c|c|c|c|c|c|c|c|}
\hline \multirow{3}{*}{ Service } & \multicolumn{4}{|c|}{ Satisfaction Level } & \multirow{2}{*}{\multicolumn{2}{|c|}{ Total }} & \multirow{2}{*}{$\begin{array}{c}\text { Uji } \\
\text { Fisher's } \\
\text { Exact }\end{array}$} & \multirow{2}{*}{$\begin{array}{c}\text { Nilai } \\
\text { phi }\end{array}$} \\
\hline & \multicolumn{2}{|c|}{ Not satisfied } & \multicolumn{2}{|c|}{ Satisfied } & & & & \\
\hline & $\mathbf{n}$ & $\%$ & $\mathbf{n}$ & $\%$ & $\mathbf{n}$ & $\%$ & \multirow{4}{*}{0,000} & \multirow{4}{*}{$\mathbf{0 , 5 8 5}$} \\
\hline Well & 6 & 10,7 & 29 & 51,8 & 35 & 62,5 & & \\
\hline Less & 16 & 28,6 & 5 & 8,9 & 21 & 37,5 & & \\
\hline Total & 22 & 39,3 & 34 & 60,7 & 56 & 100 & & \\
\hline
\end{tabular}

Table-3 shows that of the 56 with the satisfaction level of the elderly in respondents, there were $35(62.5 \%)$ the elderly Integrated Healthcare Center of 5 respondents whose services were good, it (8.9\%) respondents. Based on the results of was found that respondents who received their services were not satisfied with the satisfaction level of the elderly at the elderly Integrated Healthcare Center by 6 (10.7\%) respondents, and whose services good, it was found that respondents who got their services were satisfied with the satisfaction level of the elderly at the elderly Integrated Healthcare Center as many as $29(51.8 \%)$ of respondents. Meanwhile, of the 21 (37.5\%) respondents whose service was not good, it was found that respondents who received their services were not satisfied with the level of satisfaction of the elderly at the elderly Integrated Healthcare Center by 16 (28.6\%) respondents, and those whose services were not good, it was found that respondents who got their services Satisfied statistical tests using the Fisher's Exact Test, it was found that $p=0.000$ and which means it is smaller than the value of $\alpha=0.05$. So Ho is rejected and $\mathrm{Ha}$ is accepted means that the research hypothesis is accepted (There is a moderate relationship between the service and the satisfaction level of the elderly at the Elderly Integrated Healthcare Center in the Tobimeita Village, Kendari City). The results of the relationship closeness test using the Cramers test obtained the value of the phi coefficient of 0.585 and entered the coefficient interval $0.40-599$ in the moderate category. This shows that there is a moderate relationship between services and elderly satisfaction at the Elderly Integrated Healthcare Center in Tobimeita Village, Nambo District, Kendari City. 
d. Relationship between Officer Attitudes and Elderly Satisfaction at the Elderly Integrated Healthcare Center

Table 4. The Relationship between Officer Attitudes and Elderly Satisfaction at Elderly Integrated Healthcare Center in Tobimeita Village, Nambo District, Kendari City 2020

\begin{tabular}{|c|c|c|c|c|c|c|c|c|}
\hline \multirow{3}{*}{ Service } & \multicolumn{4}{|c|}{ Satisfaction Level } & \multirow{2}{*}{\multicolumn{2}{|c|}{ Total }} & \multirow{2}{*}{$\begin{array}{c}\text { Uji } \\
\text { Fisher's } \\
\text { Exact }\end{array}$} & \multirow[t]{2}{*}{$\begin{array}{c}\text { Nilai } \\
\text { phi }\end{array}$} \\
\hline & \multicolumn{2}{|c|}{ Not satisfied } & \multicolumn{2}{|c|}{ Satisfied } & & & & \\
\hline & $\mathbf{n}$ & $\%$ & $\mathbf{n}$ & $\%$ & $\mathbf{n}$ & $\%$ & \multirow{4}{*}{$\mathbf{0 , 0 0 0}$} & \multirow{4}{*}{$\mathbf{0 , 7 7 7}$} \\
\hline Well & 17 & 30,4 & 1 & 1,8 & 18 & $\mathbf{5 7 , 1}$ & & \\
\hline Less & 5 & 8,9 & 33 & 58,9 & 38 & 42,9 & & \\
\hline Total & 22 & 39,3 & 34 & 60,7 & 56 & 100 & & \\
\hline
\end{tabular}
respondents, there were $18(32.1 \%)$ obtained the value of the phi coefficient of respondents who had a good attitude, it was 0.777 and entered the coefficient interval found that respondents who found the 0.60-799 with the strong category. This attitude of the officers were dissatisfied with shows a strong relationship between the the satisfaction level of the elderly at the attitude of the suspect and the satisfaction of elderly Integrated Healthcare Center were 17 the elderly at the Elderly Integrated (30.4\%) respondents, and the attitude of the Healthcare Center in Tobimeita Village, officers who well, it was found that Nambo District, Kendari City. respondents who got the attitude of the officers were satisfied with the satisfaction level of the elderly at the elderly Integrated Healthcare Center by $1(1.8 \%)$ of respondents. Meanwhile, of the 38 $(67.9 \%)$ respondents whose attitude of the officers was not good, it was found that respondents who got the attitude of the officers were not satisfied with the satisfaction level of the elderly at the elderly Integrated Healthcare Center by 5 (8.9\%) respondents, and those whose attitudes were not good, were found by respondents Those who get the service are satisfied with the satisfaction level of the elderly in the elderly Integrated Healthcare Center as many as 33 $(58.9 \%)$ respondents. Based on the results of statistical tests using the Fisher's Exact Test, it was found that $\mathrm{p}=0.000$ and which means it is smaller than the value of $\alpha=0.05$. Then Ho is rejected and Ha is accepted means that the research hypothesis is accepted (There is a strong relationship between the attitude of the officers and the satisfaction level of the elderly at the Elderly Integrated Healthcare Center in the Tobimeita Village, Kendari City). The results of the relationship

\section{DISCUSSION}

Relationship between Service Quality and Elderly Satisfaction at Elderly Integrated Healthcare Center in Tobimeita Village, Nambo District

Good service quality is an important measure that is fundamental to service quality (9). This is because it provides information on the success of quality service providers with the values and expectations of patients who have their own authority to set the desired quality service standards. Patient satisfaction can be interpreted as a consumer attitude, namely some degree of liking or disliking the perceived service. In addition, patient satisfaction is a subjective value to the quality of services provided (10). Based on the results of statistical tests using the Fisher's Exact Test, it was obtained $\mathrm{p}=$ 0.000 and which means it is smaller than the value $\alpha=0.05$. So $\mathrm{Ho}$ is rejected and $\mathrm{Ha}$ is accepted means that the research hypothesis is accepted (There is a strong relationship between the quality of service and the level of satisfaction of the elderly at the Elderly Integrated Healthcare Center in Tobimeita 
Village, Kendari City). This is in line with research conducted by Sicily, 2018 with the title Relationship of Health Service Quality with Patient Satisfaction at the Shoulder Health Center of Manado City, the results of statistical tests obtained $p$ value $=0.025$ with $\mathrm{OR}=2.97$, which means that $\mathrm{Ha}$ accepted Ho is rejected, which means There is a relationship between the quality of health services and patient satisfaction at the Shoulder Health Center in Manado City. However, in this study there were 3 respondents $(5.4 \%)$ who received good service quality but were not satisfied at the level of satisfaction. This is because there are still elderly people who get unclear information about the implementation of the Integrated Healthcare Center for the elderly. In this case, the Integrated Healthcare Center cadres for the elderly should be clearer in providing information regarding the timing of implementing the Integrated Healthcare Center for the elderly. For example, information is delivered 2 or 3 days before the elderly Integrated Healthcare Center is held so that what is a problem for the elderly can be resolved. And 5 respondents (8.9\%) who received poor service quality at the Integrated Healthcare Center but experienced a level of satisfaction with the elderly Integrated Healthcare Center. This is because the elderly think that what officers provide is not good in providing services such as a lack of timeliness in providing services. In order to overcome this problem, it is hoped that the cadres will be more punctual in serving the elderly who visit first so that they do not wait for a long time.

The results of this research are in line with the research conducted by (Suhamdani 2019), at the Integrated Healthcare Center for elderly in Desa Bagi, the work area of the Bagu health center. Yang said that there is a strong relationship between cadre performance and the satisfaction level of the elderly. Service quality can be measured by comparing the perceptions between the expected service and the services received and felt by the elderly. If the quality of Integrated Healthcare Center services for the elderly who are received or felt is in accordance with expectations, then the quality of service that is perceived by the elderly is good and satisfying (5)

\section{Relationship between Service and Elderly Satisfaction in Elderly Integrated Healthcare Center in Tobimeita Village, Nambo District}

Health services are services that strive to fulfill patient expectations so that patients will feel satisfied and feel indebted and grateful. These patients will also share with others about good health services. Patient satisfaction outcomes from health services, that is why patient satisfaction is the goal of striving to improve health services. Services in the implementation of Integrated Healthcare Center activities for the elderly are one of the indicators used to measure the satisfaction of the elderly. Health services at the Elderly Integrated Healthcare Center include physical and mental emotional health checks. The results of physical health checks are recorded and monitored with a Health Card (KMS) to find out earlier the disease (early detection) or the threat of health problems being faced. Other activities that can be carried out according to local needs and conditions, such as provision of supplementary food (PMT) by taking into account the health and nutrition aspects of the elderly and sports activities such as gymnastics for the elderly, relaxing walks to improve fitness So to deal with elderly health problems, the government has issued several policies / programs implemented by the puskesmas, namely the elderly service program, also known as Integrated Healthcare Center for the elderly(11)

Based on the results of statistical tests using the Fisher's Exact Test, it was found that $p=0.000$ and which means it is smaller than the value of $\alpha=0.05$. So Ho is rejected and $\mathrm{Ha}$ is accepted means that the research hypothesis is accepted (There is a moderate relationship between the service and the 
satisfaction level of the elderly at the Elderly Integrated Healthcare Center in the Tobimeita Village, Kendari City). This is in line with research conducted by Dony entitled IHC Relations Services Elderly Elderly With Satisfaction Levels In Puskesmas Sukorambi Jember obtained data analysis techniques spearmen Rho obtained the value of $p$ is $0.000<\alpha(0.05)$, so it can be concluded that there There is a significant relationship between the Integrated Healthcare Center service for the elderly and the level of satisfaction of the elderly in Krajan Hamlet, the Work Area of the Sukorambi Community Health Center, Jember Regency. In this study, there were 6 respondents $(10.7 \%)$ who received good service for the elderly Integrated Healthcare Center but received a unsatisfied level of satisfaction with the elderly Integrated Healthcare Center. This is due to the low knowledge of the elderly about the benefits of Integrated Healthcare Center. It is hoped that the solution to the existing problem is that the cadres will be more active and improve again regarding the importance of joining the Integrated Healthcare Center for the elderly so that the elderly can be motivated to participate in the Integrated Healthcare Center for the elderly. However, the elderly still want to participate in the Integrated Healthcare Center for the elderly because the service is good. And 5 respondents $(8.9 \%)$ who received poor service quality at the Integrated Healthcare Center but experienced a level of satisfaction with the elderly Integrated Healthcare Center. This is because the elderly think that those provided by officers are not good in providing services such as a lack of timeliness in providing services. In order to overcome this problem, it is hoped that the cadres will be more punctual in serving the elderly who visit first so that they do not wait for a long time.

Respondents with less service tend to give a level of dissatisfaction with the elderly Integrated Healthcare Center. service to the elderly Integrated Healthcare Center will greatly affect how the elderly follow the Integrated Healthcare Center for the elderly. The results of this research are in line with research conducted by Katuuk EM (12), the work area of the Ranomuut Community Health Center, Paal II District, Manado City. Yang said that there was a relationship between elderly Integrated Healthcare Center services and the satisfaction level of the elderly. The quality of health services will be felt by patients if the delivery is felt to exceed the expectations of service users. Assessment of service users is aimed at service delivery, service quality, or service delivery method Muninjaya(13). In the world of service, the level of satisfaction can also prevent the elderly from joining the Integrated Healthcare Center program in their environment. This is because some elderly people think that joining the Integrated Healthcare Center program does not affect their health status. In order to provide information related to the elderly Integrated Healthcare Center, one of the most effective ways to explain the elderly Integrated Healthcare Center program is through Integrated Healthcare Center cadres to the elderly. It is hoped that the elderly who have followed the Integrated Healthcare Center program well for the elderly can maintain that the Integrated Healthcare Center program is in accordance with the procedure.

\section{The Relationship between Attitude of Officers and Elderly Satisfaction at Elderly Integrated Healthcare Center in Tobimeita Village, Nambo District}

Attitude is a tendency (tendensy) to approach (approach) or stay away (avoid), or do something, either positively or negatively towards an institution, event, idea or concept (13). Patients will feel satisfied if the Integrated Healthcare Center officers 'attitude in providing health services is the same or exceeds their expectations and vice versa, the patient's dissatisfaction or feelings of disappointment will arise if the Integrated Healthcare Center officers' attitude in 
providing health services is not in accordance with the patient's expectations. If the attitude of Integrated Healthcare Center officers at a health service facility matches their expectations, patients will always come to the health service facility for treatment. Patients will always look for health services in facilities where the performance and attitude of the health service Integrated Healthcare Center officers can meet expectations or not disappoint the patient(14). Based on the results of statistical tests using the Fisher's Exact Test, it was found that $\mathrm{p}=0.000$ and which means it is smaller than the value of $\alpha=0.05$. So Ho is rejected and $\mathrm{Ha}$ is accepted means that the research hypothesis is accepted (There is a strong correlation between the attitude of the officers and the satisfaction level of the elderly at the Elderly Integrated Healthcare Center in the Tobimeita Village, Kendari City). The results of this study are in line with the results of research conducted by Lestari et al in Tamantirto Village, Kasihan District, Bantul Regency, Yogyakarta Province, which states that there is a relationship between the attitude of the officers and the level of satisfaction of the elderly at the elderly Integrated Healthcare Center (15). However, in this study there were 17 respondents $(30.4 \%)$ who got a good attitude towards the elderly Integrated Healthcare Center but got a dissatisfied level of satisfaction with the elderly Integrated Healthcare Center.

This is due to the lack of friendly staff towards the elderly. In this case, the cadres should pay more attention to and improve hospitality as it should be in providing health services so that visitors who come or participate in the elderly activity program feel satisfied and besides that it is also hoped that the cadres will not make the elderly wait long to receive health services. In addition, there were 33 respondents $(58.9 \%)$ who found the officers lacking in the elderly Integrated Healthcare Center but experienced a level of satisfaction with the elderly Integrated Healthcare
Center, this was due to a lack of information regarding the activities and objectives carried out in the elderly Integrated Healthcare Center implementation program . From these problems, the cadres can provide solutions such as providing clearer information in conducting activities to be carried out so that the elderly can find out their purpose from here to build motivation for the elderly to participate in the implementation of the Integrated Healthcare Center for the elderly. The results are consistent with terori stating that attitude (attitude) is a reaction or response which was still closed from a person to a stimulus or object. According to Wawan (16), attitudes can be positioned as a result of evaluation of attitude objects that are expressed in cognitive, affective (emotional) and behavioral processes . From the above definitions, it is shown that attitude generally consists of cognitive components (ideas that are generally related to conversation and learning), behavior (tends to influence appropriate and inappropriate responses ) and emotions (causing consistent responses). The attitude of the officers at the community level is the Elderly Integrated Healthcare Center. The objectives of the establishment of the Integrated Healthcare Center for the elderly are to improve the health status and quality of elderly health services in the community, to achieve a happy and useful old age for the family and increase community participation in health services and communication between the elderly (17)

\section{CONCLUSION}

Based on the results of this study, it can be concluded that there is a strong relationship between service quality and elderly satisfaction levels at the Elderly Integrated Healthcare Center in Tobimeita Village, Nambo District, Kendari City 2020; There is a moderate relationship between Service and Elderly Satisfaction Levels at Elderly Integrated Healthcare Center in 
Tobimeita Village, Nambo District, Kendari City 2020; There is a strong relationship between the Attitude of Officers and the Level of Satisfaction of the Elderly at the Elderly Integrated Healthcare Center in Tobimeita Village, Nambo District, Kendari City 2020.

Based on the conclusions outlined above, the suggestions that can be given for elderly Integrated Healthcare Center cadres are expected to actively remind and motivate the elderly to follow the Integrated Healthcare Center for the elderly, besides that, in carrying out their role, cadres should also be friendly to the elderly so that the elderly feel happy to join the elderly Integrated Healthcare Center. It is hoped that the elderly can actively participate in the Integrated Healthcare Center for the elderly so that their health status can always be controlled.

\section{REFERENCES}

1. Ministry of Health of the Republic of Indonesia. Long-term Health Sector Development Plan 2005-2025. Jakarta: Ministry of Health RI; 2015 (Indonesia).

2. Nugroho. Perawatan Gerontik. Jakarta: EGC; 2015.

3. Central Bureau Statistics of Southeast Sulawesi. Southeast Sulawesi in Figures; 2019.

4. Faridah. The Relationship between Cadre Performance and Elderly Satisfaction in Optimizing the Elderly Posyandu in the Muara Kumpeh Community Health Center Area in Pudak Village. Scintia Journal Adi Wangsa University Jambi. 2018;1(1).

5. Suhamdani. Performance Relationship of Elderly Posyandu Health Cadres With Elderly Satisfaction Levels at the Elderly Posyandu in Bagu Wilaya Village Bagu Health Center Work. Health Junal Qomarul Huda. 2019;7(2).

6. Akbar MI. Analysis Of The Needs Of General Practitioners In Public Health
Centers Using Health Workload Method. Public Health of Indonesia. 2020;6(2):63-9.

7. Saraswati PS, Risky S. Correlation of supervision, opportunities for advancement and job safety with satisfaction of puskesmas employees in north konawe district. Indonesian Journal Of Health Sciences Research And Development (IJHSRD). 2019;1(1):9-21.

8. Public Health Center Abeli. Data for Elderly Integrated health Post. Kendari.2020 (Indonesia).

9. Akbar MI. Survey of patient satisfaction in hospital of North Buton District. Jurnal Kesehatan Masyarakat Celebes. 2020;1(04):1-8.

10. Iksan. The relationship between the quality of health services and BPJS patient satisfaction in the working area of the Motui Community Health Center, Konawe Regency north. 2018.

11. Effendy N. Basics of Public Health Nursing. Jakarta: EGC; 2015.

12. Ketuuk EM. Relationship between Posyandu Lanisa Services and Levels Elderly Satisfaction at the Ranomuut Health Center, Paal II District Manado City. E- Jounal Nursing (e-Kep). 2018;6(1).

13. Muninjaya AA. Health Management. 2, editor. Jakarta: EGC; 2013.

14. Poloma, Margaret M. Contemporary Sociology. Jakarta: PT. Raja Grafindo Persada,; 2016.

15. Lestari P. Several Factors Contributing to Activeness Elderly Visit to Posyandu Case Study in Tamantirto Village in Poor Bantul Regency, DIY Province. Medical journal 45, (2) 2011;45(2) (Indonesia).

16. Wawan. Knowledge, Attitude, and human behavior. Yogyakarta.: Nuha Medika.; 2010 (Indonesia).

17. Ismawati S, C. Integrated health prost and ready village. Yogyakarta: Nuha Medika; 2010 (Indonesia). 